\title{
Cadmium (Cd) concentration in the carp (Cyprinus carpio) organs at Lau Kawar Lake, Karo Regency, North Sumatra
}

\author{
Khatrin Melda Malau, ${ }^{1, *}$, Syafruddin Ilyas ${ }^{2}$, and Ternala Alexander Barus ${ }^{2}$ \\ ${ }^{1}$ Department of Biology, Faculty of Mathematics and Natural Sciences, University of Sumatera Utara \\ 20155 Medan, Indonesia \\ ${ }^{2}$ Biology Department, Faculty of Mathematics and Natural Sciences, University of Sumatera Utara, \\ Medan. Jl. Bioteknologi No. 1 Kampus USU, Padang Bulan, Medan, Indonesia
}

\begin{abstract}
Cadmium is a metal that has high toxic effects in high and low concentrations. The presence of cadmium will adversely affect the biological processes of aquatic organisms, mainly carp, which can threaten the sustainability of their lives, including humans, through the food network. Lau Kawar Lake was formed several thousand years ago when lava flowed from the Sinabung volcano and covered the Tupin River. This study aims to analyze the level of cadmium in carp organs at Lau Kawar Lake, Karo Regency, North Sumatra. The samples were taken by purposive sampling three times. Metal tests were conducted by using the Atomic Absorption Spectrometry Method. The data were analyzed through the F-test using one-way ANOVA at a 95\% confidence interval. The test results showed that the highest and lowest average cadmium levels were found in the kidneys and liver. The statistical data analysis obtained that the average Cd levels in each sample were not significantly different in the gills, kidneys, liver, and muscles. The results showed that cadmium was detected in organs of carp but was still in low levels because it had not passed the quality standard limit set by the FDR New Zealand, FAO, and FDA RI Regulations.
\end{abstract}

\section{Introduction}

Indonesia is known as a country that has a high biodiversity with the various richness of its waters. There are 3000 types of fish found in kind waters, of which 1300 species of fish live in freshwater in Indonesia [1, 2]. Lau Kawar Lake is one of the lakes in North Sumatra, precisely located at the foot of Deleting Puncak, Kuta Gugung Village, Simpang Empat District, Karo Regency. This lake formes several thousand years ago when lava flowed from the Sinabung volcano and covered the Tupin river. Lau Kawar Lake is now around 116 ha and only increased slightly after the dam builds because the sides are steep. It knows that the volume of the lake water is 41.5 million $\mathrm{m}$. The flow rate at the dam (where the lake water exits) is $25.8 \mathrm{~m}^{3} /$ minute. If it considers that the volume of water flowing from

\footnotetext{
* Corresponding author: kathyrnmelda@gmail.com
} 
the lake is as mentioned above, then based on calculations, the water will experience an exchange every three years [3].

Cadmium $(\mathrm{Cd})$ is the most common metal found in the environment, especially aquatic environments, which has a high toxic effect on the organs of living things at both high and low concentrations [4, 30]. In general, the liver and kidneys will accumulate cadmium because it has a long half-life during metabolism in organisms [30]. In humans, cadmium can be carcinogenic, damage the endocrine glands, cardiovascular system and is also present in the nervous system which, triggers neurological damage and is associated with lung, prostate, pancreatic, and kidney cancers [5]. At high concentrations, cadmium is carcinogenic, mutagenic, and teratogenic in several types of animals. That shows that the metal cadmium affects genomic and post-genomic processes in the liver, kidneys, lungs, and brain. The carcinogenic nature of cadmium causes the metal to be the first rank (Class 1) as a mutagenic agent for living organisms [6]. The presence of pollutants such as metal Cd will adversely affect the biological processes of aquatic organisms, especially fish, which can threaten the sustainability of their lives, including humans passing the food network. The resource of metals can come from natural sources such as weathering of rocks, volcanic eruptions, and atmospheric deposition. Anthropogenic sources include agriculture, livestock, domestic, and industry [7]. In addition, Cd contamination can have a pathomorphological impact on fish. The effect of $\mathrm{Cd}$ accumulation can broads divided into two is the pathophysiological and the pathomorphological result. There are several examples of the pathophysiological consequences of $\mathrm{Cd}$ on fish including, changes in fish behavior. Such changes include movement activity, morphological color, body balance, ramjet ventilation, and fish mucus production [8]. Fish organs that contain $\mathrm{Cd}$ are not well consumed by humans because $\mathrm{Cd}$ cannot metabolize, for it will accumulate in the body [28]. The accumulation of $\mathrm{Cd}$ at high concentrations cannot be accommodated by body tissues so that when it exceeds its proportion, it will cause dangerous diseases [29].

Carp (Cyprinus carpio) is a cosmopolitan fish used as a sentinel organism in toxicity bioassays and testing the physiological response in polluted media [27]. This fish is an international standard fish for toxicity tests [9]. Based on the Regulation of FDR New Zealand, FAO, and FDA RI, normal levels of Cd metal in food and processed fish is 0.1 $\mathrm{mg} / \mathrm{kg}$. If the amount of Cd exceeds the threshold value or quality standard, it can turn toxic and cause death when it accumulates in the organism's body. The research aims to analyze the level of Cd in carp organs at Lau Kawar Lake, Karo Regency, North Sumatra. This research is precisely for ecotoxicology studies in Lau Kawar Lake.

\section{Materials and methods}

This research holds in March - October 2020 in the inlet area or water input area sourced from springs located at the foot of Deleting Puncak, Kuta Gugung Village, Simpang Empat District, Karo Regency. Sampling applies three times with coordinates $3^{0} 12^{\prime} 02.60^{\prime \prime}$ North Latitude and $98^{\circ} 23^{\prime} 00.81^{\prime \prime}$ East Longitude (Fig.1). The determination of the station in this research used a survey method where the sample was taken by purposive sampling three times. Catching in the first, second, and third repetitions were 4, 5, and 5 fishes. However, only a few fish can uses because the condition of the fish does not allow it to work as a sample. The equipment used a traditional gill net, GPS (Global Positioning System). The material is fresh carp gills, liver and kidneys, liquid nitrogen, and $70 \%$ alcohol. 


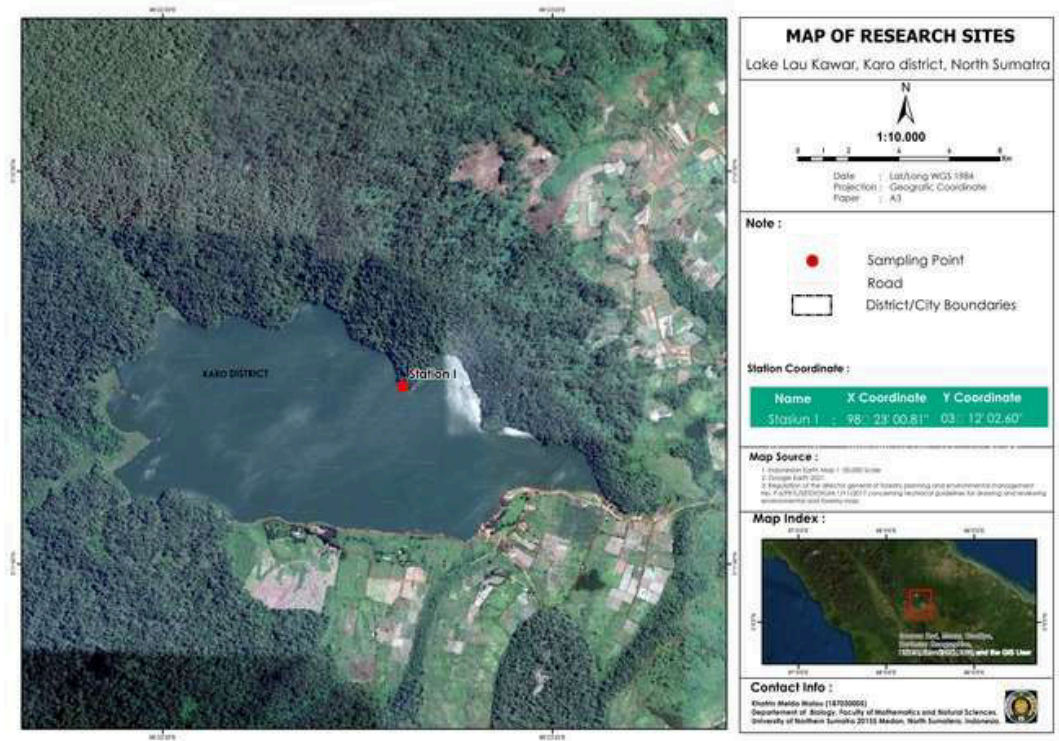

Fig. 1. Map of research sites Lau Kawar Lake, North Sumatra.

Determination of metal content carries out using the AAS (Atomic Absorption Spectrophotometric) method (detection limit $0.0001 \mathrm{ppm}$ ) [11]. Measurement of Cd levels carries out on three samples. Each one takes from fresh liver, kidneys, gills, and muscles. It takes as much as \pm 1 grams, adds $5 \mathrm{~mL}$ of concentrate $\mathrm{HNO} 3$, and is warmed up on a hot plate (furnace) to ashes. After that, added aqua-dm until the volume reached $50 \mathrm{~mL}$, stirred until homogeneous, and filtered with Whitman filter paper no.42 to measure metal content in AAS. To remove significant ions such as $\mathrm{N}^{+}, \mathrm{Ca}^{2+}, \mathrm{SO}_{-}^{4}, \mathrm{~K}^{+}$, and $\mathrm{Mg}^{2+}$, methyl isobutyl ketone, APDC, and NaDDC facilitate the metal adsorption process by AAS. The data obtained were then compared with the quality standard of Cd concentration based on FDR New Zealand, FAO, and FDA RI regulations.

The research data were analyzed descriptively using the F-test, one-way ANOVA at a $95 \%$ confidence interval to determine differences in Cd metal levels in carp organs, namely gills, liver, kidneys, and muscles [10]. The premise data analyses by ANOVA is that the sample came from an independent group, more than two groups, the variance data between groups was homogeneous and normally distributed.

\section{Results}

One of the non-essential metals whose presence in the organism's body is undesirable is cadmium. The highest average value of Cd levels was found in the kidneys, while the lowest was in the liver (Table 1) and the results of the ANOVA (Table 2).

Table 1. The average concentration of $\mathrm{Cd}$ in gills, kidneys, liver, and carp muscles.

\begin{tabular}{lccc}
\hline Cd (mg/l) & Mean & Std. Deviation & Min-Max \\
\hline Gill & 0.0017 & 0.0007 & $0.0009-0.0022$ \\
Kidney & 0.0018 & 0.0003 & $0.0016-0.0022$ \\
Liver & 0.0014 & 0.0001 & $0.0013-0.0015$ \\
Muscles & 0.0017 & 0.0009 & $0.0007-0.0025$ \\
Total & 0.0016 & 0.0005 & $0.0007-0.0025$ \\
\hline
\end{tabular}


Table 2. Results of analysis of variance in Cd levels in gills, kidneys, liver, and muscles carp.

\begin{tabular}{lccccc}
\hline & Sum of Squares & df & Mean Square & F & Sig. \\
\hline Between Groups & 0.000000313 & 3 & 0.000000104 & 0.283 & 0.836 \\
Within Groups & 0.000002953 & 8 & 0.000000369 & & \\
Total & 0.000003267 & 11 & & & \\
\hline
\end{tabular}

\section{Discussion}

Many research said that cadmium could contaminate fish tissue through food, gills, and skin penetration $[12,13,31]$. The blood absorbs cadmium and binds proteins, then distributes them throughout the tissues to accumulate $[14,31]$. In this case, temperature, $\mathrm{pH}$, salinity, DO, BOD. Waters and cadmium levels highly affect the accumulation of cadmium in fish tissue $[15,31]$. In addition, the period of fish living in contaminated water and the cadmium transfer factor from the water into the tissues also supports bioaccumulation levels $[16,17,31]$. In this research, the concentration of $\mathrm{Cd}$ in the sample showed a value still in the low category because it had not passed the quality standard limit set by the FDR New Zealand, FAO, and FDA RI regulation. Although the concentration of $\mathrm{Cd}$ in carp organs is low, the presence of $\mathrm{Cd}$ in carp must still be watched out for because of the accumulative nature of the metal itself. As known, cadmium contamination at high concentrations in aquatic biota can result in lethal, while at low concentrations results in accumulation in the body [18]. In general, it was not clear that there was the impact of pathomorphological and pathophysiological of fish due to contamination with $\mathrm{Cd}$. However, fish movement is very active, making it difficult to catch large numbers of fish. Those responses are one way for fish to survive from environmental changes to survive.

The Mean \pm SD values for Cd levels in the kidneys and liver were $0.0018 \pm 0.0003$ and $0.0014 \pm 0.0001$. Although almost the body absorbs $\mathrm{Cd}$, the highest concentrations can find in the kidneys and liver. Even about $1 / 3$ and $1 / 6$ of $\mathrm{Cd}$ in the body is stored in the kidneys and liver [19]. One influence the low concentration of $\mathrm{Cd}$ in each organ occurred is a relatively high dilution (due to higher rainfall) in the month of this research so that the mass of water from the river flows towards the lake to the sea. As a result of this dilution, $\mathrm{Cd}$ did not accumulate in large quantities in the carp's organs. The influence of the rainy season can cause the decay of metals in both water and carp [20]. This decay causes the low value of metal $\mathrm{Cd}$ in the rainy season. The higher the intensity of rain can affect decayed metals in the waters [21], which affect the high levels of metals in carp.

The result of the analysis showed that these data were homogeneous and normally distributed. The results of the ANOVA test at the 95\% confidence level obtained a significance value of 0.836 (Table 2). That means the average Cd concentration in the gills, kidneys, liver, and muscles in each sample was not significantly different because the significance value obtained was higher than $0.005(>0.005)$. Researchers observe it is affected by several factors as the carp came from the same area where the water conditions tend to be gentle and calm. As a result, carp activities are also relatively the same as food, water contamination, and mobility. For information, the sampling was carried out a week after the eruption of Mount Sinabung in 2020. Researchers observed that the highest Cd contamination came from the activities of residents such as fertilizers, pesticides used on agricultural land, and other community activities and carried away by volcanic ash from the eruption. Volcanic ash from Mount Sinabung in the lowest quantities was brought into the lake. Various studies have reported that metal $\mathrm{Cd}$ generally accumulates in the kidneys [22], liver [23, 24, 25], gills, testes, and ovaries [24], and gonads [26]. 


\section{Conclusion}

To sum up the results, it should mention that the level of cadmium in samples does not show any abnormality because it has not passed the quality standard set by the Regulation of FDR New Zealand, FAO, and FDA RI. The average value of cadmium levels in each consecutive sample is liver $<$ muscle $\leq$ gill $<$ kidney (Table 1 ). The kidney is the organ with the highest cadmium contamination found. The results of statistical data analysis obtained a significance value of 0.836 (Table 2). That means the average Cd concentration in the gills, kidneys, liver, and muscles in each fish was the same or not significantly different because the significance value obtained was higher than $0.005(>0.005)$. This study can conclude that $\mathrm{Cd}$ metal deposits have not highly accumulated in the carp organs or that $\mathrm{Cd}$ exposure is still at low concentration and still fit for consumption in reasonable amounts.

\section{Acknowledgements}

This research was funded by the Indonesian Ministry of Research, Technology and Higher Education (KEMENRISTEK-DIKTI), manage by Direktorat Riset dan Pengabdian Masyarakat (DRPM) amendment No. 28/UN5.2.3.1/PPM/KP-DPRP/2020, 14 May 2020. Thank you to all parties relating to researchers and technicians who help the smooth running and completion of this research.

\section{References}

1. I.S. Mutiara, I. Syafruddin, W. Tri, A.A. Maya, IOP Conf. Ser. Earth Environ. Sci. 130, 1 (2018)

2. U. Zega, J. Educ. Dev. 8, 3 (2020)

3. A.J. Whitten, N. Hisyam, J. Anwar, S.J. Damanik, The ecology of Sumatera (Gadjah Mada University Press, Yogyakarta, 1987)

4. J.A. Almeida, R.E. Barreto, L.B. Novelli, F.J. Castro, S.E. Moron, Neotrop. Ichthyol. 7, 103-108 (2009)

5. SJS. Flora, J. Med. Sci. 2, 4-26 (2009)

6. R. Dominggus, UNDIP Mar. Sci. 16, 2 (2011)

7. Patty, O. Jesica, S. Ratna, M.V. Pience, J. Bioslogos 8, 1 (2018)

8. Yumiarti, M. June, S. Suwirma, J. Apl. Isot. 109-113 (1996)

9. M. Filipic, T. Fatur, M. Vudrag, Hum. Exp. Toxicol. 25, 2 (2006)

10. P. Andy, Qualitative research methods in the perspective of research design (Ar-Ruzz Media, Yogyakarta, 2012)

11. M. Fatima, N. Usmani, Pak. J. Biol. Sci. 16, 9 (2013)

12. M. Fatima, N. Usmani, M.M. Hossain, J. Envi. Sci. Tech. 7, 1-15 (2013)

13. J. Thakur, M. Mhatre, Int. J. Eng. Technol. Manag. Appl. Sci. 3, 85-90 (2015)

14. L. Nayak, P.P. Mitali, D.S. Sharma, J. Atmos. 1, 1-7 (2015)

15. SI. Alam, S.A. Alam, B. Benazir, Y.A. Muhammad, A. Imtiaz, N.M. Jamal, Z. Muhammad, U. Sana, Int. J. Biosci. 3, 165-174 (2013)

16. P.S. Mangala, S.L.C. Liew, Sains Malays. 44, 1 (2015)

17. SI. Heidary, J. Namin, F. Monsefrad, Iran. J. Fish. Sci. 11, 2 (2012)

18. R. Prabowo, P. Purwanto, H.R. Sunoko, Indones. J. Nat. Sci. Educ. 39, 1 (2016) 
19. A.J. Clement, M. Salwa, Y.B. Shettima, O.V. Obioma, Am. J. Analyt. Chem. 3, 11 (2012)

20. S.M. Al-Weher, Jordan J. Biol. Sci. 1, 1 (2008)

21. D. Quig, Altern. Med. Rev. 3, 4 (1998)

22. J.A. Almeida, R.E. Barreto, L.B. Novelli, F.J. Castro, S.E. Moron, Neotrop. Ichthyol. 7, 1 (2009)

23. S. Syed Lal, A. Altindag, J. Vet. Anim. Sci. 29, 1163-1168 (2005)

24. R.V. Singanan, M. Narayanan, Int. J. Environ. Sci. Tech. 5, 2 (2008)

25. S. Dina, D. Philippe, G. Pol, P. Philippe, G. Monique, J. Mar. Sci. 65, 2 (2007)

26. APHA, Standard Methods for the examination of water and wastewater 22th Edition, (AHA, AWWA, WCF, Washington, 2012)

27. F.R. De La Torre, L. Ferrari, A. Salibian, Water Air Soil Pollut. 121, 1 (2000)

28. Junianto, Zahidah, M. Izza, Apriliani, AACL Bioflux 10, 2 (2017)

29. S.M. Praveena, C.L.S. Lin, Sains Malays. 44, 91-99 (2015)

30. W. Arifin, BS. Rahardja, K.T. Pursetyo, IOP Conf. Ser. Earth Environ. Sci. 679, 1 (2021)

31. Y.P. Dian, Jurnal Akuatek 1, 1 (2020) 